\title{
Examining the Role of Partners in Improving Innovation Performance
}

\author{
Zu'bi M. F. Al-Zu'bi ${ }^{1,2}$ \\ ${ }^{1}$ The University of Jordan, School of Business, Amman, Jordan \\ ${ }^{2}$ Visiting Professor at The University of Sydney, School of Business, Sydney, Australia \\ Correspondence: Zu'bi M. F. Al-Zu'bi, FHEA, The University of Sydney, Camperdown, 2006, NSW, Australia.
}

Received: August 13, 2019

Accepted: October 28, 2019 Online Published: October 31, 2019

doi:10.5539/emr.v8n2p64

URL: https://doi.org/10.5539/emr.v8n2p64

\begin{abstract}
The purpose of this paper is to study the innovation performance with regards to the input of collaborative partners in new product development processes leading to an innovation. A thoroughly-designed questionnaire was distributed to operations managers of 729 manufacturers. Data collected was subjected to regression analysis indicating significant comparative effect on innovation performance in favor of lead users.
\end{abstract}

Keywords: new product development, external collaboration, innovation performance, Australia, lead users

\section{Literature Review}

Innovation in products and services is the main driver of economic development in developed countries. A company with an innovative edge will be a market leader, and will enjoy all the benefits of being the first to provide a product or service, including the ability to charge high prices and to be free from competition: that is, for at least a time, the company will enjoy a monopoly. An innovative company will be able to introduce new products that are attractive to the market, and to operate with lower production costs or improved production processes (Abdallah et al., 2016). Continual innovation is therefore pivotal for any company seeking to be a market leader (Heidenreich and Kraemer, 2016; Wowak et al., 2016), and identification of effective sources of innovation is thus a focus of academics and practitioners alike.

Innovation may be derived from within a company, from activities such as research and development (R\&D) and market research or from parties external to the company (Sánchez-González \& Herrera, 2008). The latter, termed innovation sourcing, is now widely held to be essential for effective innovation (Chesbrough, 2003; Schmelzle, and Tate, 2017).

While it was initially assumed that innovation process was best performed and overseen by the company itself, with a repeating cycle of R\&D, intellectual property protection and revenue generation (Elmquist et al., 2009), competitive market demands render it very challenging for companies to innovate sufficiently rapidly on their own (Rosell \& Lakemond, 2012). As a result, there has been a paradigm shift towards innovation sourcing (Kostopoulos et al., 2011), with studies finding that half of all innovation spending focusses on external partners rather than internal R\&D, in both Europe (Gassmann, 2006) and the United States (Slowinski et al., 2009).

Innovation has been a fertile research field for many scholars over the course of the past few years. The general premise of innovation suggests that there is a plethora of ideas outside an organization's boundaries that are likely to lead to better and more commercially successful products for two main reasons. The first is that customers, suppliers, and other supply chain partners constitute a large network of sources that have the ability to exponentially increase the number of ideas which could be converted into marketable products (Chesbrough, 2003). The second is that within these three entities, there are smaller, innovative sub-groups that use their own technical skills to address new and unique problems. Consumers who adapt to new and innovative products are referred to as "lead users" (von Hippel, 1986).

As a result of this premise, there have been several research studies that aimed to explore the processes by means of various external sources leading to better products (Lilien et al., 2002). The literature concerning the process between innovation and external sources is found in both supply chain research and research on stakeholders' influences innovative performance. Literature regarding supply chains and external sources often explores how integration with external parties can improve the new product development process (Koufteros et al., 2005). Literature on the relation between stakeholders and innovation explores the characteristics of the various 
stakeholders that can improve the innovative performance of the organization (Lau et al., 2010). In this project, we aim to expand upon this stream of research by comparing the relative contribution of two key external parties, suppliers and lead users, and their effects on the innovative performance of an organization. The focus on these two external parties arises from previous research and anecdotal evidence that has shown that they can have a profound impact on the ability of an organization to develop both new and commercially successful products (Tsinopoulos \& $\mathrm{Al} \mathrm{Zu'bi,} \mathrm{2012).} \mathrm{However,} \mathrm{contrary} \mathrm{to} \mathrm{previous} \mathrm{research} \mathrm{that} \mathrm{focused} \mathrm{on} \mathrm{measuring} \mathrm{various} \mathrm{new}$ product development metrics, in this study we define and measure an organization's innovative performance in terms of six new metrics focusing on a more wholesome picture of the innovation process itself and the impact it has in order to understand how to improve the performance for each of the collaborators.

In this study, companies' innovation performance was measured using six main dimensions: futures focus; market impact; capabilities and image; process; and sustainability and overall effectiveness. This work will highlight the relative contribution of collaboration with suppliers and lead users on innovation performance, with an aim of providing consumer products manufacturers with a sustainable competitive advantage by enabling them to introduce new and demanded products to the market more succesfully than their rivals.

\section{Theoretical Framework}

Innovation is now understood to be crucial to the successful grown of entities, and identification of effective means of increasing innovation performance is now a focus not only of companies, but of entire nations (Calof, 2018). Innovation involves many stages, with various activities and partners involved in each stage (Scott \& Bruce, 1994). The practices of innovation have evolved significantly from a time when it was largely the realm of a small number of innovation practitioners, primarily in high-tech industries: now, innovation is the aim of companies across the spectrum of industries (Elmquist et al., 2009). Concerted research efforts have led to a deep knowledge of innovation (Dahlander \& Gann, 2010), with a specific focus on external innovation.

External innovation as a concept is not new: innovation has always relied on some level of external influence. For example, R\&D departments have always depended on outside knowledge (Freeman, 1974), and organizations have always relied on new ideas, often taken from other industries or from the literature, for competitive advantage (Abdallah et al., 2016; Frishammer et al., 2010; Dahlander \& Gann, 2010).

Since innovation performance is so essential to a company's success, it is important to identify which external innovation partners have the greatest impact on innovation performance. Von Hippel (1998) held that innovation was most strongly influenced by lead users, whose focus is on innovation that addresses real market needs. Other researchers, however, identify suppliers as a more significant contributor to innovation owing to their access to knowledge, resources and technology (Bidault \& Butler, 1998; Dowlatshahi, 1997; Frohlich \& Westbrook, 2001). Such opposing views mandate comparative studies.

\section{Measuring Innovation Performance}

A key challenge in understanding how to improve the innovation capacity of entities is the accurate measurement of innovation performance. Innovation performance has traditionally been quantified by adopting measures such as market share, numbers of patents or period of monopoly of the innovation, but each measure alone does not capture the complete picture. Recent research efforts have therefore attempted to identify appropriate measures that more accurately reflect the overall innovation performance of a company, with a recognition that there is a need to collect the right data, rather than collect overwhelming amounts of largely superfluous data (Neely, 2004). Determination of an appropriate set of measures for innovation performance is crucial not only to academic research, but for practitioners: self-evaluation of innovation practices is a key activity for companies seeking to improve their performance.

One of the greatest challenges in measuring innovation performance is the lack of a universally agreed-upon definition of innovation, compared to much more tangible activities such as new product development (Smith, 2005). There is also much debate about the processes that comprise innovation: for example, is research-based discovery a necessary first step of innovation? It has therefore been suggested that the measurement of innovation performance should be centered around factors that are critical for success in a particular business or sector (Birchall \& Tovstiga, 2005b), and that innovation performance should compare the innovative activities of a firm to its success in the marketplace (Tidd et al., 2001). It has also been concluded by a number of researchers that the measurement of innovation performance must take into account the nature of the innovation: whether it is institutional, revolutional or evolutional (Mezias \& Boyle, 2002).

There are numerous suggested frameworks for measuring innovation performance proposed in the literature. While some frameworks are designed to be applied at the level of the firm (Kerssens-van Drongelen \& 
Bilderbeek, 1999; Bremster \& Barsky, 2004), others are intended to be used to compare innovation between firms (Birchall et al., 2011). There are frameworks that are built around measures of the innovation process (Cooper, 1999; Birchall \& Tovstiga, 2005a), and those that measure the value of innovation optuputs (Andriessen, 2004; Copeland \& Antikarov, 2001).

Birchall et al. (2011) carried out a detailed investigation of innovation performance metrics, in an attempt to determine a set of metrics that were simple enough for application by stakeholders, did not require complex, difficult to access data, but that would still measure and cover the key aspects of innovation. They tested a range of measures and, using factor analysis, identified five measures that contribute to key factors that are essential for innovation success. The present study utilizes these measures as the dependent variable, for assessment of innovation performance.

\section{Supplier Collaboration and Innovation Performance}

There has been much prior literature highlighting the key roles of supplier collaboration in the new product development (NPD) process, and the various advantages of such partnerships (Bidault \& Butler, 1998; Frohlich \& Westbrook, 2001). The suppliers' technical expertise can provide a forum for the evaluation and improvement of ideas during both the initial stages of the innovation process, and later, during its testing phases. Suppliers with technical knowledge are well-placed to assist NPD teams advance existing products and ideas; and address technical questions more rapidly than internal R\&D teams (Haeussler et al., 2012).

Suppliers are well-placed to support the incremental improvement of existing products, through providing technical expertise to increase modularity and therefore lead to a high number of products in a product family (Alford et al., 2000; Halman et al., 2003), as well as providing the technical autonomy to invest and develop subsystems that can then be used by a buyer during the final assembly stage (Kamath \& Liker, 1995). However, qualified suppliers are also able to enhance innovativeness and performance of newly-developed products (Abdallah \& Matsui, 2007; Al-Zu'bi et al., 2015).

The challenges of supplier collaboration in NPD include contradicting objectives of the two partners (Littler et al., 1995), and barriers to the open sharing of knowledge, particularly when it relates to core competencies. This can arise from a hesitancy of internal employees to working with external partners (Frishammer et al., 2010).

Previous studies have demonstrated that supplier collaboration has a positive effect on NPD in terms of product variety (Al-Zu'bi \& Tsinopoulos, 2012), product development time (Tsinopoulos \& Al-Zu'bi, 2012) and NPD cost (Tsinopoulos \& Al-Zu'bi, 2014). While these studies highlight the importance of supplier collaboration on NPD, they do not provide a complete picture of the effect of this partnership on innovation performance. No study has provided an understanding of the effect of supplier input on innovation performance. It is clear, however, that suppliers have the deep knowledge of the market and consumer needs, as well as the technological capability to contribute positively to innovation performance. This leads to the first hypothesis:

H1: Supplier collaboration in NPD will be positively and significantly related to innovation performance.

\section{Lead User Collaboration and Innovation Performance}

Lead users have been defined as a unique group of consumers who possess specific needs that are unknown to the wider public, and benefit from helping to find a solution to those needs (von Hippel, 1986). Lead users also possess knowledge that is relevant to an organization's products and product development (Morrison et al., 2000), and are therefore seen as an essential source of information regarding market needs and expectations. This knowledge of the market can enable companies to overcome competitors by the development of innovative new products (Luthje \& Herstatt, 2004).

Lead users have long been regarded as a key source of innovation (Lilien et al., 2002), and there has therefore been a focus on identifying ways in which they can be most effectively engaged in the NPD process. The demonstrated benefits of lead user collaboration in NPD include decreased cycle and product development times, lower costs, and greater product quality (Lonsdale \& Newell, 1996; Hamann, 1999; Al-Zu'bi \& Tsinopoulos, 2012; Tsinopoulos \& Al-Zu'bi, 2014).

Potential drawbacks of collaboration with lead users include disruption of internal processes (Abdalla \& Phan, 2007), and the risks of leaking internal knowledge and of achieving only incremental innovation (Frishammer et al., 2010; Dahlander \& Gann, 2010). Furthermore, it has been noted that, as with suppliers, collaboration with lead users can be hindered if the two parties have different objectives (Eliashberg et al., 1997). Regardless of these potential challenges, it is generally agreed that lead users are likely to benefit a company's new product development process, but no study has directly investigated the effect of lead user collaboration on innovation behavior. We therefore propose the following hypothesis: 
H2: Lead user collaboration in NPD will be positively and significantly related to innovation performance.

\section{Methodology}

\subsection{Data Collection}

Data for this study was collected by means of a survey, in which respondents were asked to answer questions using a five-point Likert scale, in which 5 signifies strong agreement and 1 signifies strong disagreement. The constructs for partner collaboration in NPD were adapted from Al-Zu'bi, Z.M.F. (2016), and the constructs for innovation performance from Birchall et al. (2011). Following pilot-testing of constructs were pilot-tested by three professors of business management, and subsequent revisions, the survey was administered to 1200 manufacturing companies in Australia, encompassing both local and multinational companies. The questionnaire was sent to the NPD manager, operations manager or plant manager of each company. In total, 840 questionnaires were returned, with 111 excluded from further analysis due to missing data. The 729 usable questionnaires corresponded to a response rate of $60.75 \%$, which is regarded a high response rate for studies in the field of operations management (Frohlich \& Westbrook, 2001)

\subsection{Measurement Analysis}

Construct validity was tested using exploratory factor analysis (EFA) using the Varimax rotation method (Hair et al., 2010), with the criteria that all items for a construct had factor loadings of greater than 0.4 and an eigenvalue greater than 1. Kaiser-Meyer-Olkin measure of sampling adequacy and Bartlett's test of sphericity were carried out to confirm that the data was appropriate for further analysis. The construct reliability was tested using the Cronbach's $\alpha$-coefficient, with all coefficients above the threshold of 0.70 , confirming sufficient reliability and internal consistency (Table 1).

Table 1. Means, standard deviations, and Cronbach's $\alpha$-coefficient

\begin{tabular}{lllll}
\hline Variable & Mean & $\begin{array}{l}\text { Standard } \\
\text { deviation }\end{array}$ & $\begin{array}{l}\text { Cronbach's } \\
\text {-coefficient }\end{array}$ & $\begin{array}{l}\text { Final number } \\
\text { of question } \\
\text { items }\end{array}$ \\
\hline 1. Supplier collaboration in NPD & 3.77 & 0.444 & 0.799 & 8 \\
2. Lead user collaboration in NPD & 3.33 & 0.499 & 0.777 & 8 \\
3. Innovation performance & 3.90 & 0.511 & 0.801 & 6 \\
\hline
\end{tabular}

Exploratory factor analysis results are shown in Table 2. Eight question items measured supplier collaboration in NPD, Eight items measured lead user collaboration in NPD which is in line with Al-Zu'bi, Z.M.F. (2016) and Six question items measured innovation performance which is different result than that of Birchall et al (2011) by which the results divided the last measurement of sustainability and overall effectiveness into two separate loadings; which does not affect the study's dependent variable as much it shows uniqueness in response and measurement.

Table 2. Exploratory factor analysis

\begin{tabular}{lll}
\hline & $\begin{array}{l}\text { We consult suppliers early in the design efforts for new } \\
\text { products. }\end{array}$ & $\mathbf{0 . 8 0 1}$ \\
& $\begin{array}{l}\text { We partner with suppliers for the design of new products. } \\
\text { Suppliers are frequently consulted about the design of } \\
\text { the new products. }\end{array}$ & $\mathbf{0 . 7 7 7}$ \\
$\begin{array}{l}\text { Suppliers are involved in the new product project only } \\
\text { after the design is completed. }\end{array}$ & $\mathbf{0 . 7 5 5}$ \\
Supplier & $\begin{array}{l}\text { Suppliers are an integral part of the design effort for the } \\
\text { new products. }\end{array}$ & $\mathbf{0 . 8 9 9}$ \\
in NPD & $\begin{array}{l}\text { Suppliers are involved in specifying product } \\
\text { specifications for the new products. }\end{array}$ & $\mathbf{0 . 7 3 3}$ \\
\hline
\end{tabular}


Suppliers are consulted in setting general new product

definition.

Suppliers are involved in the new product process from the start to the finish.

We consult lead users early in the design efforts for new 0.799 products.

We partner with lead users for the design of new $\mathbf{0 . 7 0 5}$ products.

Lead users are frequently consulted about the design of $\mathbf{0 . 9 0 5}$ the new products.

Lead users collaboration in NPD
Lead users are involved in the new product project only after the design is completed.

Lead users are involved in specifying product $\mathbf{0 . 8 5 5}$ specifications for the new products.

Lead users are an integral part of the design effort for the $\mathbf{0 . 7 8 3}$ new products.

Lead users are consulted in setting general new product definition.

Lead users are involved in the new product process from $\mathbf{0 . 9 0 0}$ the start to the finish.
Innovation performance
Our innovation process utilizes better internal project management than others'

Our innovation process caters for sustainability better than others'

Our innovation process is more effective than others'

Extraction method: Principal component analysis

Rotation method: Varimax with Kaiser Normalisation

\section{Results and Analysis}

The hypotheses of this study were tested using regression analysis. The skewness measured by normality tests, of between -0.112 and 0.132 , were consistent with normally-distributed data (Hair et al., 2010). The variance inflation factors (VIF) for the independent variables were below 1.3, confirming that analysis was not compromised by multicollinearity, despite any correlations between the independent variables. (Hair et al., 2010).

The first step of multiple regression analysis involved entering control variables into the hierarchical regression model, with the results showing that the control variables did not significantly affect innovation performance (Adj. $R^{2}=0.018$ Table 3 ). This was followed by inputting of the independent variables into the regression model, which revealed that the independent variables did have significant contribution to innovation performance (Adj. $R^{2}=0.018$; Table 3). Both supplier collaboration $(\beta=0.345)$ and lead user collaboration $(\beta=0.489)$ had significant effects on innovation performance. Based on these results, both hypotheses $\mathrm{H} 1$ and $\mathrm{H} 2$ are accepted. 
Table 3. Hierarchical Regression Model: Company’s Innovation Performance

\begin{tabular}{|c|c|c|c|c|c|}
\hline & \multicolumn{2}{|c|}{ Unstdized Coeffs } & \multirow{2}{*}{$\begin{array}{l}\text { Stdized } \\
\text { Coeffs } \\
\text { Beta }\end{array}$} & \multirow{2}{*}{$\mathrm{t}$} & \multirow{2}{*}{ Sig. } \\
\hline & $\mathrm{B}$ & Std. Error & & & \\
\hline \multicolumn{6}{|l|}{ Step 1} \\
\hline (Constant) & 7.543 & .324 & & 10.001 & .000 \\
\hline Company size (number of employees) & -.071 & .023 & -.033 & -.444 & .965 \\
\hline Sector of Industry & .055 & .015 & .022 & .634 & .833 \\
\hline Length of relationship & .043 & .064 & .092 & 1.654 & .222 \\
\hline $\mathrm{r}$ & .150 & & & & \\
\hline$R^{2}$ & .0225 & & & & \\
\hline Adjusted $R^{2}$ & .018 & & & & \\
\hline Regression $F$-value & 5.006 & & & & \\
\hline \multicolumn{6}{|l|}{ Step 2} \\
\hline (Constant) & 4.554 & .421 & & 9.111 & .000 \\
\hline Company size (number of employees) & -.030 & .029 & -.019 & -.408 & .785 \\
\hline Sector of Industry & .046 & .011 & .013 & .543 & .722 \\
\hline Length of relationship & .009 & .052 & .063 & 1.064 & .204 \\
\hline Supplier Collaboration in NPD & $.401 *$ & .256 & $.345^{*}$ & 3.336 & .000 \\
\hline Lead Users Collaboration in NPD & $.556^{*}$ & .019 & $.489 *$ & 4.551 & .000 \\
\hline $\mathrm{r}$ & .822 & & & & \\
\hline$R^{2}$ & .675 & & & & \\
\hline Adjusted $R^{2}$ & .601 & & & & \\
\hline$R^{2}$ Change & .6525 & & & & \\
\hline Regression $F$-value & 8.434 & & & & \\
\hline
\end{tabular}

\section{Conclusion}

This study investigated the effects of supplier and lead user collaboration in NPD on innovation performance of manufacturing companies in Australia. The analysis revealed a strong positive relationship between collaboration with both lead users and suppliers and innovation performance, although the relationship is stronger for lead user collaboration. The results emphasize the importance of external collaboration on innovation performance. New ideas with high quality are not restricted to internal R\&D, but the innovation process can be accelerated and enhanced by involving suppliers and lead users. In today's highly competitive environment, organizations can enhance their competitive advantage by focusing on external alliances and collaboration in NPD. External alliances enable manufacturers to increase and maintain competitive advantages despite declining R\&D budgets.

The study highlights the essential role of lead user collaboration in innovation. It is not surprising that lead user collaboration showed higher impact on innovation performance than supplier collaboration. Lead users are invaluable sources of new innovative ideas that are represent the future needs of the markets. Companies missing lead user collaboration may not be able to catch up with competitors in the era of globalization and high environmental uncertainly. Overall, this study demonstrates that external alliances have a significant impact on innovation performance with regards to the six metrics used.

The limitation of this paper is that only two external collaborators were investigated: it is possible that there are other external collaborators who also favorably influence the innovation performance. Further in-depth research is needed to investigate how suppliers and lead user collaboration influence different innovation models in services and manufacturing sectors. 


\section{Acknowledgement}

The author gratefully acknowledges the Arab Fund for Economic and Social Development-the Distinguished Scholar Program for their support of this research.

\section{References}

Abdallah, A. B. (2009). Just-in-time production, supporting practices, and mass customization: Their relationships and impact on competitive performance. Unpublished doctoral dissertation. Yokohama National University, Japan.

Abdallah, A. B., Anh, P. C., \& Matsui, Y. (2016). Investigating the effects of managerial and technological innovations on operational performance and customer satisfaction of manufacturing companies. International Journal of Business Innovation and Research, 10, 153-183. https://doi.org/10.1504/IJBIR. 2016.074824

Abdallah, A. B., \& Matsui, Y. (2007). The relationship between JIT production and manufacturing strategy and their impact on JIT performance. In Proceedings of the 18th Annual Production and Operations Management Society (POMS) Conference. Dallas, USA.

Abdallah, A., \& Phan, C. A. (2007). The Relationship between Just-In-Time Production and Human Resource Management, and Their Impact on Competitive Performance. Yokohama Business Review, 28, 27-57.

Alford, D., Sackett, P., \& Nelder, G. (2000). Mass customisation - an automotive perspective. International Journal of Production Economics, 65, 99-110. https://doi.org/10.1016/S0925-5273(99)00093-6

Al-Zu'bi, Z. M. F., \& Tsinopoulos, C. (2012). Suppliers versus Lead Users: Examining Their Relative Impact on Product Variety. Journal of Product Innovation Management, 29, 667-680. https://doi.org/10.1111/j.15405885.2012. 00932.x

Al-Zu'bi, Z. M. F., Tarawneh, E., Abdallah, A. B., \& Fidawi, M. (2015). Investigating Supply Chain Integration Effects on Environmental Performance in the Jordanian Food Industry. American Journal of Operations Research, 5, 247-257. https://doi.org/10.4236/ajor.2015.54019

Al-Zu'bi, Z. M. F. (2016). Investigating the Effect of External Alliances on Innovation Behavior in the European Union Industrial Sector. American Journal of Operations Research, 6, 105-112. https://doi.org/10.4236/ ajor.2016.62013

Andriessen, D. (2004) Making Sense of Intellectual Capital: Designing a Method for the Valuation of Intangibles, Butterworth-Heinemann, Oxford. https://doi.org/10.4324/9780080510712

Bidault, F., Charles, D., \& Butler, C. (1998). New product development and early supplier involvement (ESI): The drivers of ESI adoption. International Journal of Technology Management, 15, 49-70. https://doi.org/10.1504/IJTM.1998.002593

Birchall, D. W., Chanaron, J.-J, Tovstiga, G., \& Hillenbrand, C. (2011). Innovation performance measurement: Current practices, issues and management challenges. International Journal of Technology Management, 56, 1-20. https://doi.org/10.1504/IJTM.2011.042492

Birchall, D. W., \& Tovstiga, G. (2005a). Capabilities for Strategic Advantage: Leading Through Technological Innovation, Palgrave Macmillan, Basingstoke. https://doi.org/10.1057/9780230522497

Birchall, D. W., \& Tovstiga, G. (2005b). Innovation Performance Measurement in Organisations, Henley Management College (internal report), Henley-on-Thames, Henley Management College, UK.

Bremster, W. G., \& Barsky, N. P. (2004) Utilizing the balanced scorecard for R\&D performance measurement, $R \& D$ Management, 34, 229-238. https://doi.org/10.1111/j.1467-9310.2004.00335.x

Calof J. (2018) Enhancing Innovation Performance in Companies. Foresight and STI Governance, 12, 30-33.

Chesbrough, H. (2003) Open Innovation: The New Imperative for Creating and Profiting from Technology. Boston: Harvard Business School Press.

Copeland, T., \& Antikarov, V. (2001) Real Options - A Practitioner's Guide, Texere, New York.

Dahlander, L. and Gann, D. (2010). How Open is Innovation? Research Policy, 39, 699-709.

Dowlatshahi, S. (1997). The role of product design in designer buyer-supplier interface. Production and Planning Control, 8, 522-532.

Freeman, C. (1974) The Economics of the Industrial Revolution. London: Pinter. 
Eliashberg, J., Lilien, G. L. and Rao, V. R. (1997). Minimizing technological oversights: A marketing research perspective. In R. Garud, P. R. Nayyar, \& Z. B. Shapira (Eds.), Technological Innovation: Oversights and Foresights, Cambridge University Press, Cambridge.

Frishammer, J., Grönlund, J., \& Sjödin, D. (2010). Open Innovation and the Stage-Gate Process: A Revised Model for New Product Development. California Management Review, 52, 106-132.

Frohlich, M. T., \& Westbrook, R. (2001). Arcs of integration: an international study of supply chain strategies. Journal of Operations Management, 19, 185-200.

Gassmann, O. (2006) "Opening Up the Innovation Process: Towards an Agenda." R\&D Management, 36, 223-28.

Haeussler, C., Patzelt, H., \& Zahra, S.A. (2012). Strategic alliances and product development in high technology new firms: The moderating effect of technological capabilities, Journal of Business Venturing, 27, 217-233.

Hair, J. R., Black, J. F., Babin, B. J., \&Anderson, R. E. (2010). Multivariate data analysis (7th ed.). Macmillan, New York.

Halman, J. I. M., Hofer, A. P., \& Vuuren, W. V. (2003). Platform-driven development of product families: linking theory with practice. The Journal of Product Innovation Management, 20, 149-162.

Hamann, U. (1999). Health Awards Recognise Innovation and Performance: The Significance of Innovation in the Semiconductor Industry for Performance in Chip Card Applications. The Lamp, 56, Part, 11

Heidenreich, S., \& Kraemer, T. (2016) Innovations-Doomed to Fail? Investigating Strategies to Overcome Passive Innovation Resistance. Journal of Product Innovation Management, 33, 277-97.

Kamath, R. R., \& Liker, J. K. (1995). A Second Look at Japanese Product Development. The Journal of Product Innovation Management, 12, 253

Kerssens-van Drongelen, K. and Bilderbeek, J. (1999) R\&D performance measurement: more than choosing a set of metrics, $R \& D$ Management, 29, 35-46.

Kostopoulos, K., Papalexandris, A., Papachroni, M., \& Ioannou, G. (2011) Absorptive Capacity, Innovation, and Financial Performance. Journal of Business Research, 64, 1335-43.

Koufteros, X., Vonderembse, M., Jayaram, J. (2005). Internal and external integrationfor product development: the contingency effects of uncertainty, equivocality, and platform strategy. Decision Sciences, 36, 97-133

Lau, A. K. W., Yam, R. C. M., \& Tang, E. P. Y. (2010). The impact of technological innovation capabilities on innovation performance: An empirical study in Hong Kong, Journal of Science and Technology Policy in China, 1, 163-186

Lilien, G. L., Morrison, P. D., Searls, K., Sonnack, M., \& Von Hippel, E. (2002). Performance assessment of the lead user idea-generation process for new product development. Management Science, 48, 1042-1059.

Littler D., Leverick, F., \& Bruce, M. (1995). Factors affecting the process of collaborative product development: a study of UK manufacturers of information and communications technology products. Journal of Product Information Management, 12, 16-32.

Lonsdale, R., \& Newell, S. F. (1996). Classification of sources of new product ideas. Handbook of New Product Development, John Wiley and Sons, New York

Luthje, C., \& Herstatt, C. (2004). The Lead User method: an outline of empirical findings and issues for future research. $R \& D$ management, 34, 553-568.

Mezias, S. J., \& Boyle, E. (2002). Organizational Dynamics of Creative Destruction: Entrepreneurship and the Emergence of Industries, Palgrave Macmillan, Basingstoke.

Morrison, P. D., Roberts, J. H., \& Von Hippel, E. (2000). Determinants of user innovation and innovation sharing in a local market. Management Science, 46, 1513-1527. https://doi.org/10.1287/mnsc.46.12.1513.12076

Neely, A. (2004). Performance measurement: the new crisis. In S. Crainer, \& D. Dearlove (Eds.), Financial Times Handbook of Management, Pearson Education Ltd, Harlow.

Rosell, D. T., \& Lakemond, N. (2012) Collaborative Innovation with Suppliers -A Conceptual Model for Characterising Supplier Contributions to NPD. International Journal of Technology Intelligence and Planning, 8, 197-214. https://doi.org/10.1504/IJTIP.2012.048477

Sánchez-González, G., \& Herrera, L. (2008). Cooperation for innovation: the impact on innovatory effort. 
Documentos de Trabajo FUNCAS, No. 409.

Schmelzle, U., \& Tate, W. (2017). Integrating External Knowledge: Building a Conceptual Framework of Innovation Sourcing. Transportation Journal, 56, 477-512. https://doi.org/10.5325/transportationj.56.4.0477

Scott, S., \& Bruce, R. (1994). Determinants of Innovative Behavior: A Path Model of Individual Innovation in the Workplace. The Academy of Management Journal, 37, 580-607. https://doi.org/10.2307/256701

Schuhmacher, A., Gassmann, O., McCracken, N., \& Hinder, M. (2018). Open innovation and external sources of innovation. An opportunity to fuel the R\&D pipeline and enhance decision making? Journal of Translational Medicine, 16, 119. https://doi.org/10.1186/s12967-018-1499-2

Slowinski, G., Hummel, E., Gupta, A., \& Gilmont, E. R. (2009). Effective Practices for Sourcing Innovation. Research Technology Management, 52, 27-34. https://doi.org/10.1080/08956308.2009.11657546

Smith, K. (2005). Measuring innovation. In J. M. D. C. Fagenberg, \& R. R. Nelson (Eds.), The Oxford Handbook of Innovation (pp. 147-179). Oxford University Press, Oxford. https://doi.org/10.1093/oxfordhb/ 9780199286805.003 .0006

Tidd, J., Bessant, J., \& Pavitt, K. (2001). Managing Innovation: Integrating Technological, Market and Organisational Change. John Wiley, Chichester.

Tsinopoulos, C., \& Al-Zu'bi, Z. M. F. (2011). Clockspeed effectiveness of lead users and product experts. International Journal of Operations and Production Management, 32, 1097-1118. https://doi.org/ 10.1108/01443571211265710

Tsinopoulos, C., \& Al-Zu'bi, Z. M. F. (2014). Lead users, suppliers, and experts: the exploration and exploitation trade-off in product development. International Journal of Technology Marketing, 9, 6-20. https://doi.org/10.1504/IJTMKT.2014.058080

Von Hippel, E. (1986). Lead Users: A Source of Novel Product Concepts. Management Science, 32, $791-805$. https://doi.org/10.1287/mnsc.32.7.791

Von Hippel, E. (1998). Economics of product development by users: The impact of 'sticky' local information. Management Science, 44, 629-644. https://doi.org/10.1287/mnsc.44.5.629

Wowak, K. D., Craighead, C. W., Ketchen, D. J., \& Hult, G. T. M. (2016). Toward a 'Theoretical Toolbox' for the Supplier-Enabled Fuzzy Front End of the New Product Development Process. Journal of Supply Chain Management, 52, 66-81. https://doi.org/10.1111/jscm.12084

\section{Copyrights}

Copyright for this article is retained by the author(s), with first publication rights granted to the journal.

This is an open-access article distributed under the terms and conditions of the Creative Commons Attribution license (http://creativecommons.org/licenses/by/4.0/). 